\title{
Law enforcement practices of employment of elderly people in the modern society context
}

\author{
Elena Nikolaevna Kasarkina $^{1}$ and Alena Aleksandrovna Antipova \\ Mordovia State University, Institute of History and Sociology, Department of Sociology and Social \\ Work, Saransk, Russia
}

\begin{abstract}
Research objective is to study the position of elderly people in the labour market in the modern society context and highlight trends in the social protection of their interests in the field of labour. The paper used both quantitative and qualitative research methods. Such research methods as analysis, synthesis, interpretation, structural-functional approach, classification, typology, grouping, generalisation and interpretation of the information received were chosen. The main research method was the method of a pilot questionnaire survey of older people, as well as a comparison of the author's research data with empirical research on the problem in question. The research resulted in conclusions from the analysis of the elderly people employment problem in the context of the legislative reform of raising the retirement age and the tendency for the demand for elderly people employment as an objective necessity. The authors believe that society is interested in active longevity and cannot develop if it does not consider the employment of elderly people as a social progress indicator. The scientific novelty of the research is the relevance of the new concept "unemployed elderly" in the context of modern society is argued; highlighted are the contradictions in solving the elderly people problems in the labour market associated with the need to increase the retirement age; the author's vision of the factors contributing to the labour activities of elderly people is presented; the advantages of the labour potential of elderly people are highlighted.
\end{abstract}

Keywords: retirement, employment, services, assistance

\section{Introduction}

A society cannot be called civilized if it does not help people in hardships, in particular, the elderly population. Russia is a social state; therefore, resources should be found to ensure social protection of the elderly. However, the society's needs for well-being, economic development, a strong army, quality education and medicine often run counter to the adequacy of social protection measures for the elderly. We can note the contradiction between the objective situation expressed in the society's needs for development based on the able-bodied population and the need to socially protect the needy, in particular the elderly which involves money, professionals, hospitals, etc.

\footnotetext{
${ }^{1}$ Corresponding author: eienovik@mail.ru
} 
The needs of the society for elderly people can be reflected in the following: transfer of knowledge, skills and their role in the socialisation of the younger generation; use of experience in ensuring communication between generations; solving the spiritual and moral problems of society through the life experience of elderly people as custodians of the most important values; the social potential of elderly people.

In the modern Russian society, the urgent elderly people employment problem has emerged. The entry into force of the law on raising the retirement age on January 1, 2019 [1], consolidated a new pension reform, according to which, by 2032, the retirement age for women will increase to 60 years, for men to 65 years. On the other hand, the population is aging. According to the 2018 forecast by the Russian Ministry of Labour, in 2021, the proportion of people over working age in the total population will be $26.7 \%$ and reach 39.5 million people [2].

The employment of elderly people as a subject of social protection is studied by Grigorieva [3], Sukhobskaya [4], Vorontsova [5], Kolosnitsyna [6], Medvedeva [7], and Nagornova [8]. The need of society to use the labour resources of elderly people was analysed by Lazebnik [9], Lezhnina [10], and Prokopenko [11].

The position of elderly people in the labour market is considered when analysing the research papers of Bogdanova [12], Barsukova [13], Zharkova [14], Sannikova [15], and Shchanina [16].

Recommendations for the social protection of the interests of elderly people in the field of labour were noted by Nikonova [17], Petrova [18], Smirnova [19], and Chentsova [20].

Adaptation to old age depends on many factors, one of which has a positive impact the possibility of extending the employment relationship. Employment is used as an important and widely used indicator of the social well-being of elderly people. In Russia, elderly people, who want to continue to conduct work activities until they reach retirement age, encounter difficulties. In Russian law enforcement practices, there is no concept of "elderly workers" which makes it difficult to solve the elderly people employment problem and puts workers of pre-retirement and retirement age in a vulnerable position. The research focuses on studying the position of elderly people in the labour market in the context of modern society and highlight trends in the social protection of their interests in the field of labour. To achieve the goal of the research, it is necessary to tackle such problems as considering the social protection of elderly people in the field of work in the modern society; describe the law enforcement practices of employment of elderly people; highlight the possibilities of active longevity of elderly people in the context of modern society.

Research hypothesis. The traditional view of elderly people as passive subjects of the labour market is becoming irrelevant. Within the framework of the law enforcement practice of employment of elderly people in the context of modern society, a subjective and active position of elderly people as a demanded labour force is gradually generated.

\section{Methods}

The work used both quantitative and qualitative research methods. The main method was the method of aerobatic questionnaire survey of elderly people who applied for help at the State Budgetary Institution of the Republic of Moldova Integrated Centre for Social Services in the Urban District of Saransk, Chamzinsky Population Employment Centre, Department of Social Protection of the Population for the Atyashevsky District Employment Centre Chamzinsky, Department of the Department of Social Protection for Bolshebereznikovsky District, Chamzinsky Population Employment Centre (108 people interviewed). The empirical basis was a secondary analysis of research on the problem in question 


\section{$3 \quad$ Results}

The results of empirical data analysis are shown in Table 1.

Table 1. Analysis of the elderly people employment practice in the context of modern society.

\begin{tabular}{|c|c|c|}
\hline $\begin{array}{l}\text { Study, region, } \\
\text { year }\end{array}$ & Key results & $\begin{array}{l}\text { Conclusions of the author's pilot study } \\
\text { (Republic of Mordovia, 2020) }\end{array}$ \\
\hline $\begin{array}{l}\text { The relationship } \\
\text { between labour } \\
\text { and rocial } \\
\text { activities } r \text { of } \\
\text { elderly persons. } \\
\text { (Khabarovsk } \\
\text { Territory, 2011) } \\
\text { [21] }\end{array}$ & $\begin{array}{l}\text { Elderly people are highly } \\
\text { motivated to continue working. } \\
\text { Elderly people with higher } \\
\text { education are most active from } \\
\text { the point of view of labour } \\
\text { activities. }\end{array}$ & $\begin{array}{l}\text { A significant proportion of elderly people } \\
\text { are motivated to engage in work. For those } \\
\text { with higher education, continuation of work } \\
\text { is associated with some interest in work - } \\
58.9 \% \text {, habit of work }-29.5 \% \text {, desire to } \\
\text { avoid loneliness }-35.6 \% \text {. For elderly } \\
\text { people, who do not have a higher education, } \\
\text { the continuation of work is due to the fact } \\
\text { that the pension does not allow maintaining } \\
\text { an accentable living standard }(76.8 \%)\end{array}$ \\
\hline $\begin{array}{l}\text { The social } \\
\text { situation of } \\
\text { Russian } \\
\text { pensioners in the } \\
\text { modern context } \\
\text { (Irkutsk region, } \\
2013-2016) \text { [22] }\end{array}$ & $\begin{array}{l}\text { Adaptation to retirement age } \\
\text { depends on many factors, one of } \\
\text { which has a positive impact, the } \\
\text { ability to extend the } \\
\text { employment relationship. Low } \\
\text { involvement of pensioners in } \\
\text { labour relations can be } \\
\text { explained by objective reasons } \\
\text { (health, unemployment rate in } \\
\text { the region) and subjective } \\
\text { reasons (ageism). }\end{array}$ & $\begin{array}{l}31 \% \text { of elderly people, who continue to } \\
\text { work and are satisfied with their job, rate } \\
\text { their aging as "successful more often". A } \\
\text { consequence of unfulfilled need or interests } \\
\text { in employment }(69 \%) \text { is a decrease in the } \\
\text { quality of life, socially unprotected aging. }\end{array}$ \\
\hline $\begin{array}{l}\text { Employment of } \\
\text { elderly people } \\
\text { (Kemerovo, } \\
2018)[23]\end{array}$ & $\begin{array}{l}\text { Employment of elderly persons } \\
\text { is of increasing importance to } \\
\text { society. }\end{array}$ & $\begin{array}{l}\text { The importance of longevity for an } \\
\text { individual is defined in their own way but } \\
\text { they are significant for society: the need to } \\
\text { take care of someone }(72.45 \%) \text {; striving for } \\
\text { self-realisation }(48.98 \%) \text { active social and } \\
\text { political activities }(15.31 \%) \text {; life experience } \\
(18.37 \%) \text {. The obstacles to active aging are } \\
\text { negative stereotypes of old age, } \\
\text { gerontophobia }(54.08 \%) \text {; health problems } \\
\text { (85.71\%); pecuniary hardships }(85.71 \%) \text {. }\end{array}$ \\
\hline $\begin{array}{l}\text { Entrepreneurship } \\
\text { of the elderly } \\
\text { (Saint Petersburg, } \\
\text { 2019) [24] }\end{array}$ & $\begin{array}{l}\text { Within the framework of the law } \\
\text { enforcement practice of } \\
\text { employment of elderly people in } \\
\text { the contest of modern society, a } \\
\text { subjective and active position of } \\
\text { elderly people as a demanded } \\
\text { labour force is gradually } \\
\text { generated. }\end{array}$ & $\begin{array}{l}11 \% \text { of respondents are ready for individual } \\
\text { entrepreneurship, } 9 \% \text { have experience. }\end{array}$ \\
\hline
\end{tabular}

\section{Discussion}

In modern legal instruments, there is no concept of "unemployed" which would refer to an elderly person. The action strategy in the interests of citizens of the older generation in the Russian Federation notes "based on the general tendency of population aging and the reduction of labour resources, the need for the economy to use the labour of elderly people will grow every year. In this regard, it is one of the important directions of the state policy of the Russian Federation and is of great importance to promoting employment of the 
elderly citizens from both the point of view of ensuring the income of the elderly, using their educational and labour potential in the interests of the country's economy, and from the point of view of socialisation. elderly people, their integration into society. In recent years, there has been a steady upward trend in the employment of pensioners. After retirement, every second pensioner continues to work". However, not all pensioners manage to exercise their right to work. In pilot regions, sociological surveys of elderly people were conducted, in their opinion, the employment is complicated due to the lack of vacancies $(45.2 \%)$, the low level of wages $(23.0 \%)$, inappropriate working conditions (13.7\%), lack of required qualifications (6.7\%), age and health limits $(11.4 \%)$ [25].

According to the Federal State Statistics Service (Rosstat), in 2019 more than 196,000 citizens of senior working age would like to work, were looking for work and were ready to start working. Citizens of pre-retirement age, whose share in the total number of registered unemployed at the end of December 2018 was $9.2 \%$, also experienced difficulties in finding employment. According to the survey of the population employment problems among unemployed citizens classified in accordance with the ILO criteria, persons aged 50-59 accounted for $16.8 \%$ and those aged $60-72$ accounted for $2.9 \%$ [26]. According to the research results in Russian regions, both young people and elderly people are not competitors to each other in the labour market, contrary to the prevailing stereotype. Those two categories, the youth and the elderly occupy different niches in the labour area [27].

Many overseas researchers consider employment to be the most important population health and quality indicator. A similar point of view is shared by R. Sharma, who argues that employment is used as an important widely used indicator of public health [28]. Lutz and Kebede proved that an increase in the level of education, employment is a significant factor in the growth of the average life expectancy of the population [29]. By analysing the relationship of general health spending with GDP and life expectancy, Zaman, Hossein, Mehta, Sharmin and Mahmoud came to the conclusion that the population of most countries has a high chance of survival due to technological progress, employment and improved social assistance [30]. The focus is on the relationship between the quality of the population, its life expectancy and the social and economic development of European countries [31]. Jones, Lenart and Baudisch, came to the conclusion that in the second half of the $20^{\text {th }}$ century improved health of the population and an increase in life expectancy were due to an increase in survival in older age groups. The improvement in the survival rate of elderly people is caused by the "postponement" of the onset of senile mortality [32].

\section{Conclusion}

1. The modern society feels the need to protect the interests of elderly people in the field of work. However, compulsory measures to engage elderly people to work predominate without meeting their interests (raising the retirement age, increased dependence of the size of pensions on the size of contributions to pension funds).

2. Society is interested in active longevity and cannot develop if it does not consider the employment of elderly people as a social progress indicator.

3. The concept of "unemployed elderly" is relevant for the modern society. Those are people who have reached retirement age and receive pensions but can be counted as unemployed when looking for work and willing to work.

4. The state has a concern in increasing the retirement age more than the elderly themselves. Employment of the elderly is vital for the state as an opportunity to reduce the burden in the area of pension payments, although this does not completely remove budgetary tension. 


\section{References}

1. Federalnyi zakon "O vnesenii izmenenii v otdelnye zakonodatelnye akty Rossiiskoi Federatsii po voprosam naznacheniya i vyplaty pensii” ot 03.10.2018 № 350-FZ (poslednyaya redaktsiya) [Federal Law "On Amendments to Certain Legislative Acts of the Russian Federation on the appointment and payment of pensions" dated 03.10.2018 No. 350-FZ (latest version)]. Accessed on: July 1, 2021. [Online]. Available: http://www.consultant.ru/document/cons_doc_LAW_308156/

2. Doklad o rezultatakh kompleksnogo monitoringa sotsialno-ekonomicheskogo polozheniya pozhilykh lyudei za 2018 god [Report on the results of comprehensive monitoring of the social and economic situation of elderly people for 2018]. Accessed on: July 1, 2021. [Online]. Available: https://rosmintrud.ru/docs/1340

3. I.A. Grigorieva, L.A. Vidyasova, A.V. Dmitrieva, O.V. Sergeeva, Pozhilye v sovremennoi Rossii: mezhdu zanyatostyu, obrazovaniem i zdorovem [Elderly in Modern Russia: between Employment, Education and Health] (Aleteya, Saint Petersburg, 2015)

4. G.S. Sukhobskaya, V.A. Rodionov, Sotsialnaya podderzhka pozhilykh lyudei [Social Support to the Elderly] (Tuscarora, Irkutsk, 2001)

5. M.V. Vorontsova, Sotsialnaya zashchita pozhilykh grazhdan v sovremennom rossiiskom obshchestve [Social Protection of Senior Citizens in Modern Russian Society] (Branch of the RSSU, Taganrog, 2010)

6. M.G. Kolosnitsyna, M.A. Gerasimenko, Iss. State and Munic. Manag. 4, 47-68 (2014)

7. G.P. Medvedeva (ed.), Sotsialnaya rabota s pozhilymi lyudmi: monografiya [Social Work with the Elderly: Monograph] (RUSAYNS, Moscow, 2017)

8. A.Yu. Nagornova (ed.), Pozhilye lyudi: strategii sotsialnoi pomoshchi: kollektivnaya monografiya [Elderly People: Social Assistance Strategies: Collective Monograph] (Zebra, Ulyanovsk, 2016)

9. L.B. Lazebnik, Yu.V. Konev, L.I. Efremov, Clin. Geront. 16(1-2), 48-52 (2010)

10. Yu.P. Lezhnina, Reform. Rus. 7, 178-195 (2008)

11. N.A. Prokopenko, Adv. Geront. 29(1), 182-188 (2016)

12. E.A. Bogdanova, J. Soc. Pol. Research 4, 535-550 (2016)

13. V.N. Barsukov, Econ. Soc. Changes: Facts, Trends, Forec. 1, 195-211 (2016)

14. S.L. Zharkova, V.A. Tsygankov, Sotsialno-ekonomicheskie problemy truda lits pozhilogo vozrasta [Socio-Economic Problems of Labour of Elderly People] (Economics, Moscow, 2011)

15. L.I. Sannikova, Puti sokhraneniya lichnostnogo potentsiala pozhilogo cheloveka [Ways to Preserve the Personal Potential of an Elderly Person] (Publishing House of the Perm National Research Polytechnic University, Perm, 2012)

16. E.V. Shchanina, Power, 8, 151-155 (2017)

17. E.I. Nikonova, Proc. Kazan Univ. 151(5-2), 61-70 (2009)

18. Zh.V. Petrova, Innov. Activ. 4(39), 104-110 (2016)

19. T.V. Smirnova, Professionalnye resursy v pozhilom vozraste [Professional Resources in Old Age] (Publishing House of the Saratov State Technical University, Saratov, 2008)

20. E.V. Chentsova, Soc. Serv. Worker 10, 17-23 (2016)

21. E.V. Boykova, L.K. Zolotareva, Power and Manag. East Rus. 4, 125-131 (2011) 
22. T.B. Anshukova, Sotsialnoe polozhenie rossiiskikh pensionerov v sovremennykh usloviyakh (na primere Irkutskoi oblasti) [Social Status of Russian pensioners in Contemporary Conditions (by the example of the Irkutsk region)], PhD Thesis in Social Science (Buryat State University, Ulan-Ude, 2017)

23. A.M. Chelombitko, Formirovanie razvitie zanyatosti pozhilykh lyudei v sovremennoi ekonomike Rossii [Promotion of Development of Employment of Older People in the Modern Economy of Russia], PhD Thesis in Economics (Kemerovo State University, Kemerovo, 2018)

24. A.V. Smirnova, Formirovanie organizatsionno-ekonomicheskogo mekhanizma vovlecheniya lits starshego vozrasta $\mathrm{v}$ sferu predprinimatelstva [Development of an Organisational and Economic Mechanism for Involving Older Persons in the Field of Entrepreneurship], PhD Thesis in Economics (St. Petersburg State University of economics, Saint Petersburg, 2019)

25. Strategiya deistvii v interesakh grazhdan starshego pokoleniya v Rossiiskoi Federatsii do 2025 goda [Strategy of actions in the interests of older citizens in the Russian Federation until 2025]. Accessed on: July 1, 2021. [Online]. Available: https://mintrud.gov.ru/docs/government/173

26. Federalnaya sluzhba gosudarstvennoi statistiki [Federal State Statistics Service]. Accessed on: July 1, 2021. [Online]. Available: http://www.gks.ru/

27. V.Yu. Lyashok, S.Yu. Roshchin, J. New Econ. Assoc. 1, 117-140 (2017)

28. R. Sharma, PLoS ONE, 13(10), e0204940 (2018). https://doi.org/10.1371/journal.pone.0204940

29. W. Lutz, E. Kebede, Popul. and Devel. Rev. 44(2), 343-361 (2018). https://doi.org/10.1111/padr.12141

30. S. Zaman, N. Hossain, V. Mehta, et al., J. Med. Res. Innov. 1(2), 7-12 (2017). https://doi.org/10.5281/zenodo.576546

31. G. Miladinov, Genus, 76, 2 (2020). https://doi.org/10.1186/s41118- 019-0071-0

32. J.A. Barthold Jones, A. Lenart, A. Baudisch, PLoS ONE, 13(7), e0197985 (2018). https://doi.org/10.1371/journal.pone.0197985 